\title{
David Garrick: Saints, Temples and Jubilees
}

\section{Peter Holland}

\section{OpenEdition \\ Journals}

Electronic version

URL: http://journals.openedition.org/shakespeare/3020

DOI: $10.4000 /$ shakespeare.3020

ISSN: 2271-6424

\section{Publisher}

Société Française Shakespeare

\section{Electronic reference}

Peter Holland, « David Garrick: Saints, Temples and Jubilees », Actes des congrès de la Société française Shakespeare [Online], 33 | 2015, Online since 16 March 2015, connection on 02 June 2020. URL : http:// journals.openedition.org/shakespeare/3020; DOI : https://doi.org/10.4000/shakespeare.3020

This text was automatically generated on 2 June 2020

(c) SFS 


\title{
David Garrick: Saints, Temples and Jubilees
}

\author{
Peter Holland
}

1 I begin with Shakespeare's birthdays, precisely and perversely because they will prove not to be relevant to what follows, neither the anniversary of the date of Shakespeare's birth nor the group of references to birthdays in Shakespeare ${ }^{1}$. Of the latter there are four in all: Cassius tells Messala before the battle at Philippi, "This is my birthday" (Julius Caesar, 5.1.71); Cleopatra lets Antony know "It is my birthday" (Antony and Cleopatra, 3.13.187); one of the fishermen informs Pericles that Simonides has "a fair daughter, and tomorrow is her birthday" (Pericles, 5.150-1); and Pirithous thanks Arcite because "You have honoured her fair birthday with your virtues" (Two Noble Kinsmen, 2.5.36). ${ }^{2}$ Three of the birthdays are women's: Cleopatra, Thaisa and Emilia. Cassius uses a strange collocation to mention his birthday, going on to explain to Messala, "....as this very day / Was Cassius born" (71-2), as if the first statement needed a gloss. Strikingly, all four of the references to birthdays in Shakespeare are in classical plays. No-one in a play set in England or Britain is noted for having a birthday.

2 The tendency in early modern Europe was to celebrate not birthdays but name-days, the day of the saint with whom one shared a first name, something more pronounced in Catholic countries than in Protestant ones. I shall have more to explore on Shakespeare's link to saints' days later. For now, let me just note that neither Garrick's Jubilee in 1769 nor the Shakespeare day that Goethe celebrated two years later with the speech for the Strasbourg commemoration had anything to do with Shakespeare's birthday. And let me also note for now that passage in Goethe's "Zum ShakespearesTag" where classical religion makes its appearance: "Shakespeare, mein freund", "Shakespeare, my friend, if you were still with us, I could live nowhere but with you; how gladly I should play the supporting role of a Pylades to your Orestes, rather than the dignified character of a high priest at the temple at Delphi", "eines Oberpriesters im Tempel zu Delphos". ${ }^{3}$ Whatever else may have been happening in the classical allusions that were part of celebrating and commemorating Shakespeare for Garrick and Goethe, no-one seems to have connected the event either with Shakespeare's own 
birthday or his examples of birthdays. The link that is so natural to us - Shakespeare is to be celebrated on or about April $23^{\text {rd }}$ - does not figure at all. Celebrating Shakespeare was not for a day but for the whole year.

3 This tale of temples and monuments, idolatry and jubilation begins with a moment that I have usually considered simply as an act of cultural tourism, a sightseeing trip by three sisters visiting London from Bristol, their home town, but which I want here to see in the complex context of the creation of the Shakespeare religion, something I will want to redefine as a moment as much of anxiety as of celebration as well as a moment of religious incoherence and imprecision.

When she was 29, Hannah More, the brilliant young playwright, spent the winter season of 1773-4 in London with her two sisters, Sarah and Martha, the first of what would be annual trips to the capital for all of them. They were well connected, perhaps now one should say "networked", with a letter of introduction to Sir Joshua Reynolds' sister who introduced them to, among others, Dr Johnson. Among the trips they made from the flat they rented near Covent Garden, one was along the Thames to Hampton to see the villa, set in six acres, that David Garrick had bought in 1754 and which, for more than twenty years, would be altered, extended and decorated on the advice of the innovative architect and designer Robert Adam, pretty much unknown when Garrick first hired him. They had not yet met Garrick - that would not happen until the following year. Perhaps their connections made it possible to drop by as visitors but perhaps the house and grounds were already on the tourist trail. They had spent the day visiting Claremont, the Palladian house near Esher in Surrey, seat of the Duke of Newcastle designed by Vanbrugh, and went to Garrick's villa on their way back to town.

When the sisters visited, the house was yet again undergoing building work, as it would need again after a serious fire in 2008, but Hannah was pleased "infinitely" by Garrick's gardens and she visited Garrick's Shakespeare temple, the "grateful temple to Shakespeare" as Horace Walpole called it, ${ }^{4}$ that in 1755 Garrick had had designed, possibly by Adam, about forty yards away from the house, on the river frontage. It is, as far as I know, the first temple dedicated to a writer; indeed, I am hard put to it to find another, since the so-called Dante Temple at the Villa Melzi on Lake Como acquires its name only because of the statue of Dante and Beatrice near it. Part of my concern in this article is precisely the sheer oddity of Garrick's project, magnified by the fact that no-one seems to have found it odd.

6 The design of Garrick's temple, whoever the architect was, was clearly derived from the temple at nearby Chiswick House designed by William Kent, which was, in effect, a combination of a rotunda or cella, probably derived from the Pantheon in Rome, and a portico designed after the building often referred to then as the temple of Fortuna Virilis, now known as the temple of Portunus. As well as involving the young architect Robert Adam in the ongoing project of the villa, gardens and possibly the temple, Garrick also commissioned four paintings of the grounds from Johann Zoffany, then, like Adam, still in his twenties. The four showed the house and garden with Garrick reading; a garden view with two of his nieces playing; the Garricks taking tea in the garden with Colonel Boden, while Garrick's brother George fishes; and, the best known of the four, Mr and Mrs Garrick outside the Shakespeare Temple. The last exists in two versions, one including their nephew playing in the portico and with a servant arrived from the house to serve tea, the other without these figures. ${ }^{5}$ I emphasize the fact of 
this being a group of paintings because of the extent to which the villa was, for Garrick, the epitome of his status as a gentleman, complete with house, garden and garden folly.

The temple contained some of Garrick's greatest treasures. "Here", wrote Hannah to a friend in Bristol, "is the famous chair, curiously wrought out of a cherry tree" - she should have written "a mulberry tree" - "which really grew in the garden of Shakespeare at Stratford. I sat in it, but caught no ray of inspiration." 6

8 For Hannah, there was no epiphany from the chair, no transformational moment from this equivalent of the wood of the true cross (and, given the astonishing number of objects supposedly created from this one mulberry tree, it did have the prodigious powers of cloning itself that the true cross seems also to have had). Garrick seems to have had no doubt about the provenance of his mulberry chair, even though in his play The Jubilee he has two competing vendors arguing about whose goods are made from the real tree:

Don't buy of that fellow, your honor, he never had an inch of the Mulberry Tree in his life. His goods are made out of old chairs and stools and colored to cheat gentlefolks with. It was I, your honor, bought all the true Mulberry Tree. ${ }^{7}$

In the absence of such a sacred moment as Hannah More hoped to have from sitting in the chair, her experience returned to the human, indeed the emphatically somatic:

But what drew, and deserved, my attention was a most noble statue of this most original man, in an attitude strikingly pensive - his limbs strongly muscular, his countenance strongly expressive of some vast conception, and his whole form seeming the bigger from some immense idea [with] which you suppose his great imagination pregnant. ${ }^{8}$

The statue, which can be glimpsed through the door in Zoffany's painting, had been commissioned by Garrick in 1757 from the sculptor Louis François Roubiliac at a cost, Hannah More noted, of "five hundred pounds" (other accounts suggested the price was only 300 guineas but that was still a huge sum). Garrick's fame was established on his special bond with Shakespeare and his plays but the statue was marked by a more particular identification than a quasi-religious adoration. The adoration was of course mixed with gratitude for Shakespeare's part in Garrick's successful career and the wealth it had brought him, the (good) fortune that had enabled him to buy the Hampton villa, build the temple and commission the statue. Nonetheless, the statue was seen and probably intended as more than that mix of awe and thanks: a widespread contemporary rumour suggested that the statue was not only for Garrick but also of him, that Garrick was the model as well as the patron, that Garrick was here performing or becoming Shakespeare, an assumption magnified for us by two strikingly similar paintings of Roubiliac working on the maquettes of two statues, one of Shakespeare (painted by Adrien Carpentiers) and one of Garrick (painting by Andrea Soldi). Roubiliac's pose is virtually identical in each, only the subject has changed - if it really has: in effect, Roubiliac sculpted Garrick twice.

10 I mentioned Walpole's description of the temple as a sign of Garrick's being "grateful" to Shakespeare. Walpole, indeed, wrote for Garrick a motto to ornament the building: "Quod spiro et placeo, si placeo tuum est". In a letter, Walpole offered a translation:

That I spirit have, and nature,

That sense breathes in every feature, 
That I please, if please I do,

Shakespear, all I owe to you.

But, he wrote, "his [Garrick's] modesty would not let me decorate it". 9

For Garrick, respect for Shakespeare was akin to - or perhaps identical with - an act of faith and this temple was not only jokingly the appropriate place in which to worship a divine being. As he wrote to a French friend, the translator and journalist Jean Suard, in 1765, "I will not despair of seeing you in my temple of Shakespeare, confessing your infidelity, and bowing your head to the god of my idolatry, as he himself so well expresses it" and, anticipating a visit to Hampton by other French gentlemen, Garrick looked forward to a day "when we shall throw all dramatic critics and critical refinements into the Thames, and sacrifice to Shakespeare". ${ }^{10}$ As Juliet encourages Romeo to swear "by thy gracious self, / Which is the god of my idolatry" (Romeo and Juliet, 2.1.155-6), so Garrick's friend must bow to Shakespeare - and Garrick, like a high priest, was Shakespeare's earthly "representative": in 1758, the London Magazine published some verse, supposedly "dropt in Mr. Garrick's Temple of Shakespeare", in which Shakespeare's voice identifies Garrick anew:

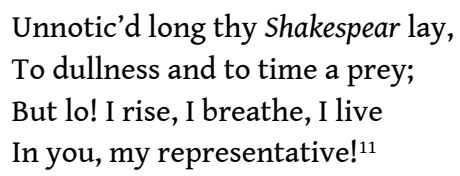

The appropriation of Juliet's line to Romeo to describe Garrick's reverence towards Shakespeare would reappear near the opening of Garrick's "Ode" at the Stratford Jubilee. In response to the question

To what blest genius of the isle, Shall Gratitude her tribute pay, Decree the festive day, Erect the statue, and devote the pile?

comes the answer:

'Tis he! 'tis he! - that demi-god!

...'Tis he! 'tis he!

"The god of our idolatry!" 12

And I find something troubling about Garrick's blandness - perhaps even blindness - to the oddity of this use. Shakespeare may be semi-divine but neither he nor Romeo is a god and what in Juliet seems to me to be a consciousness of the excess and of the sinful danger inherent in idolatry is turned by Garrick into unabashed glorying in this inappropriateness, in what the OED rather sternly defines as "immoderate attachment to or veneration for any person or thing; admiration savouring of adoration" (n. 2). What kind of religion did Garrick want this new veneration of Shakespeare to be and how does it stand in relation to more conventional religion? I do not for a moment think he was particularly sure, least of all about its relationship to more conventional forms of Christianity. Garrick was, of course, a Protestant, descended from a Huguenot family, but his wife was a Catholic; when they married, on 22 June 1749, they had two ceremonies on the same day, the second a Catholic rite in the chapel of the Portuguese Embassy. ${ }^{13}$ Mrs Garrick went to Mass throughout her long, long life - and she outlived Garrick by more than four decades. Certainly the confused and confusing nature of this 
new religion was an anxiety for some contemporaries. An attack on the Ode in a contemporary newspaper The Public Ledger comments first on Garrick's terming Shakespeare a "demi-god":

Had the Author been a little more conversant with the Pagan Mythology, he would have known that the title a Demi-God was never conferred but on Heroes. This is the first time it was ever applied to a Poet. ${ }^{14}$

But that shift from "demi-god" to "god" was even more troubling:

But, he [Garrick] seems to think, that even the rank of a Half-God was far too low for Shakespeare; and therefore, in a few lines after, he makes him a whole god...Well said Christian! But it is no wonder he should endeavor to make a God of Shakespear, since he has usurped the office of his High-priest; and has already gained money enough by it, to make a golden calf, to be an object of that idolatry which he recommends... This extravagant expression, which is pardonable from the mouth of a young girl distracted with love, and applied to her lover, he uses as his own serious sentiment, and that of all the good People of this Realm, with regard to Shakespear. ${ }^{15}$

14 Eventually, inevitably, the transition from Shakespeare to Garrick would occur: in his long poem The Task (published in 1785), a work which capaciously manages to include almost anything, William Cowper found space to turn the god of our idolatry into Garrick, not Shakespeare:

...Garrick's mem'ry next,

When time hath somewhat mellow'd it, and made

The idol of our worship while he liv'd

The god of our idolatry once more,

Shall have its altar; and the world shall go

In pilgrimage to bow before his shrine. ${ }^{16}$

Roubiliac's statue was certainly not the first monument of and to Shakespeare. The bust in Holy Trinity Church in Stratford-upon-Avon was in place by 1623 . The recognition of Shakespeare as a national figure was signalled in 1735 by his being placed, along with Milton and Pope, as one of the representative British poets among the sixteen figures in the Temple of British Worthies created by William Kent for Viscount Cobham in his gardens at Stowe and using some of the busts, including Shakespeare, by John Michael Rysbrack that had earlier stood in the Fane of Pastoral Poetry, designed by Gibbs and erected in 1728. Kent's temple is essentially not a space sacred to a divinity but to the memory of a hero or to an heroic quality, here the modern worthies, positioned in the garden to face the grander Temple of Ancient Virtue which contained four statues, exemplars of the arts of war, philosophy, poetry and law (Epaminondas, Socrates, Homer and Lycurgus). So the British worthies included poets and philosophers, monarchs and architects, eight for action and eight for thought. Shakespeare's contribution to this is that, as the tablet above the bust announces, he is the one " Whose excellent Genius open'd to him the whole Heart of Man, all the Mines of Fancy, all the Stores of Nature; and gave him Power, beyond all other Writers, to move, astonish, and delight Mankind". Shakespeare may be excellent but he is not unique and, I would note, Hannah More was just as excited, just before visiting Garrick's Shakespeare temple, to visit Alexander Pope's house and gardens, the "haunts of the swan of Thames", for "what an enthusiastic ardour I have ever had to see this almost sacred spot." ${ }^{17}$ Indeed, as Joseph Roach has intriguingly pointed out, ${ }^{18}$ Joseph Nickolls' 
painting of Pope's villa at Twickenham (ca. 1755) shows in the garden a temple and obelisk, neither of which was in fact ever in Pope's garden, as if either the Chiswick House temple (which has an obelisk in front of it) or Garrick's temple (which does not) had been transplanted there, so that, for Nickolls, the "swan of Thames" is linked to the "swan of Avon" via Garrick (as usual).

If Stowe's temple is, in some senses, a sacred spot it is an unusual one. Technically a roofless exedra, it is a temple without an interior, an open, public space, not one that defines its meaning by analogy to classical temples or churches. It is strikingly unlike any of the other temples at Stowe, for example, the Temple of Concord and Victory or the Gothic Temple. Its form desacralizes its meaning, turning its parade of worthies into something less than sacred, more heroic. One would not here expect to find that "ray of inspiration," that semi-divine spark of genius that Hannah More hoped to find from the mulberry chair in Garrick's temple. The bust of Shakespeare at Stowe has no signs of the heroic body that she saw in the "strongly muscular" limbs of Roubiliac's statue. As patriotic project, Stowe is not about the supra-human nor about the bodily presence, that which lies below the head and shoulders of the bust, that which so overexcited Hannah More.

But the supra-human, semi-divine Shakespeare has a long history, reaching its apogee long after Garrick's or Hannah More's conceptions of it in Sir Sidney Lee's proposal for a change in the nation's saint. In 1900, in a lecture to the Royal Institution of Great Britain on "Shakespeare and true Patriotism," Lee began by comparing Shakespeare and St George as candidates for England's patron saint:

If at the beginning of a new century a patron saint was chosen anew, and the choice lay between a mythical native of Cappadocia and Shakespeare, the native of Stratford-on-Avon, the straitest of cosmopolitan intellects among us could hardly defy the sentiment that gave the preference to the Englishman. ${ }^{19}$

The complete absence in Shakespeare's biography or afterlife of any of the prime requirements for sainthood, such as the performance of miracles through the saint's intercession, seems never to have crossed Lee's mind.

Shakespeare had already been defined as a saint long before Sir Sidney Lee's advocacy. In 1660 John Phillips published his parodic almanac, Montelion, 1660 or The Prophetical Almanack. Parody almanacs became formulaic, based on the models used in examples from the late Interregnum. They included, for instance, lists of the time since various events, some real, some not, some significant, others trivial, many jokey, often sexual or scatological. Each month listed its saints' days, as one would expect in any almanac, but with a radically unusual group of saints. January 1660 includes classical authors like Ovid, Cicero and Petronius, and Chaucer, as well as Country Tom and Fair Rosamond. But January $8^{\text {th }}$ is the day of "Pericles Prince of Tyre" and the $5^{\text {th }}$ of "Andronicus". The former was noted in 1924 by George Thorn-Drury as a Shakespeare allusion but he missed the latter, which is, I suspect, an allusion to the play. ${ }^{20} 2^{\text {nd }}$ May brings "Jack Falstaff" and then, on $4^{\text {th }}$ May, "Shakespear" - the fact that the latter is not too far from Shakespeare's "birth"- and death-day is, I am sure, no more than an accident. ${ }^{21}$ Montelion, 1660 is the only example I have yet come across in the parody almanacs that includes Shakespeare as a saint. But the Montelion for the following year, not by Phillips, has Falstaff again, now on May $6^{\text {th }}$. 
In 1662 William Winstanley began the long series of almanacs he published as "Poor Robin", and Falstaff turned up frequently as one of the saints in the double calendar, one liturgical, one parodic, he listed month by month. In Poor Robin for 1668, for instance, he is on $11^{\text {th }}$ January, in $167531^{\text {st }}$ January, in $167611^{\text {th }}$ January and $167725^{\text {th }}$ January. There is an exuberant energy in Winstanley's lists of parodic saints; as Frank Palmeri comments, in a fine article on the parody almanacs,

Poor Robin's list draws its parodic saints from such widely disparate realms as picaresque and satiric literature, Greek history, English folklore, Italian literature, imperial Roman history, chivalric romance, criminal history, British political history, Shakespearean and other British drama, Elizabethan fiction, French fables, European mythology, the history of Catholicism and Anabaptism. ${ }^{22}$

Winstanley, who, not surprisingly, was running out of inspiration the longer the series continued, quoted the winter part of the final song in Love's Labour's Lost for a number of wintry months (for example, Poor Robin for 1670 and 1679),

When icicles hang by the wall,

And Dick the shepherd blows his nail,

And Tom bears logs into the hall,

And milk comes frozen home in pail... (LLL, 5.2.897-900)

Winstanley's pamphlets are peppered with Shakespeare quotations, allusions and references, so that, for instance, Poor Robin's Intelligence for August 1677 mentions that "we read in antient Chronicles of the Merry Wives of Windsor, and find the jolly Dames of Wapping celebrated by more modern Authors". ${ }^{23}$ There are many more to be found than Thorn-Drury identified.

Winstanley would make his best-known contributions to the praise of Shakespeare first in one of the lives added to the second version of England's Worthies in 1684 (Shakespeare and Jonson as the examples of playwrights among the 72 worthies) and then expanded in his Lives of the Most Famous English Poets (1687), which covered 168 poets in all. Here Shakespeare is "This eminent Poet, the Glory of the English Stage (and so much the more eminent, that he gained great applause and commendation when able Wits were his Contemporaries)". ${ }^{24}$ But the significance he accords Shakespeare can be seen in the frontispiece to the entire volume which places a bust of Shakespeare between monuments to Chaucer and Cowley. Unnoticed until an article by Jackson Boswell in 2009, ${ }^{25}$ this engraving by Frederick Hendrick Van Hove clearly gives Shakespeare pride of place, even by comparison with Chaucer, to whom Winstanley, quoting Heylin, gives "first place of our chiefest Poets", and Cowley whom he calls "the Glory of our Nation". ${ }^{26}$ The line from this bust to the one in Cobham's Temple of British Worthies is a short one - and the connection of the name of Cobham's Temple with the title of Winstanley's English Worthies is, I suspect, no accident. But, even as Cobham was having his temple built, there were already signs of the campaign to have Shakespeare appropriately memorialised in marmoreal form in Westminster Abbey, a movement that gathered force once a bust of Milton had been placed there in 1737. The author of an early elegy on Shakespeare, William Basse, had argued that Shakespeare should be placed beside Chaucer, Spenser and Beaumont in the Abbey, making of their tomb a bed for four, adequate till Doomsday since "hardly will a fifth / Betwixt this day and that by Fate be slain". It may be for Basse "a sacred sepulchre" but we are a long way here from Shakespeare as saint, however ironically. 
Basse's proposal was, of course, one that Ben Jonson strongly resisted, proclaiming, in his elegy on Shakespeare printed in the First Folio, that Shakespeare did not need such a memorial: "Thou art a Moniment, without a tombe, / And art alive still while thy Booke doth live".

But others were not so sure and were determined that a monument in Westminster Abbey would be exactly what Shakespeare would have. Even if the body could not be moved from Stratford and buried in the Abbey, there was no reason why a memorial could not be in the capital's gathering of the great and the dead. The statue by Peter Scheemakers was unveiled in 1741 and later revised when the blank scroll towards which Shakespeare gestured and which contemporary satirists mocked for its blankness was filled by inaccurately quoted lines from The Tempest. Often reproduced in prints and soon available as a small porcelain souvenir, the Abbey monument was a sign of Shakespeare's cultural value. It was a version of this statue, not the one in Garrick's temple, that would stand in the midst of the orchestra for the performance of Garrick's "Ode" at the Jubilee. ${ }^{27}$

The words in Shakespeare's voice about his being "Unnotic'd long" hugely overstated the case for seeing the playwright as neglected before Garrick's arrival on London's theatrical and social scene. ${ }^{28}$ But the myth continued, finding its place at the end of the century in an inscription on the plinth of another statue: a contemporary described the statue of Garrick put up in Westminster Abbey in 1797 as showing Garrick "throwing aside a curtain, which discovers a medallion of the great Poet...The curtain itself is designed to represent the Veil of Ignorance and barbarism, which darkened the drama of the immortal bard till the appearance of Garrick", while the inscription explains the meaning further:

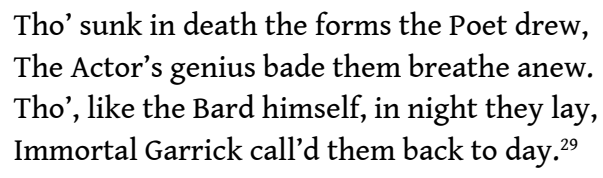

Visit Garrick's Shakespeare temple now to admire its 1990s restoration and you will not find the Roubiliac statue, only a reproduction of it. In his will, as the symbolicallyplaced second item, after the disposition of the Hampton estate, Garrick left the statue to the British Museum where it stood in the King's Library until the opening of the new British Library where, instead, it stands at the foot of the library's main staircase. Garrick plainly wished to have it seen as occupying a different kind of space from the temple; no longer part of religious fervour but instead as part of the national collection of the genius of the country that the new museum and its central feature, the library, were intended to symbolize. In many ways, Garrick's Shakespeare religion was always a matter of celebrating the genius of the nation. One might worship at the Shakespeare temple or by reading in the British Museum or by going to the theatre or even by going on pilgrimage to the birthplace of the saint. That this is various and not exactly thought through is only appropriate: Garrick is an actor-manager, not a theologian, and his aim was always a Shakespeare cult, rather than a church. The transpositions of location for the act of faith is therefore characteristic and, for Garrick, probably desirable. where the sacred space of Shakespeare should be, no longer in Westminster Abbey nor 
in Holy Trinity church in Stratford-upon-Avon. In his prologue for the new season in 1750, Garrick defined the Shakespeare religion as belonging in the theatre itself: "Sacred to Shakespeare was this spot design'd, / To pierce the heart, and humanize the mind."

But, as Garrick well knew, especially given his responsibilities as manager, it all depends on the audience's taste - even a sacred spot can remain empty:

But if an empty House, the Actor's curse,

Shews us our Lears and Hamlets lose their force:

Unwilling we must change the nobler scene,

And in our turn present you Harlequin. ${ }^{30}$

And Harlequin, as Garrick would have remembered from one of his first appearances on the London stage, was perfectly capable of absorbing Shakespeare and even the celebration of Shakespeare as statue, playwright and divinity. Henry Giffard's Harlequin Student (1741), in which Garrick took the role of Harlequin when Richard Yates fell ill, ends with the arrival of Jupiter announcing that "Immortal Shakespear's matchless Wit revives, / And now the Bard in speaking Marble lives", after which "The Scene draws and discovers the monument of Shakespear, exactly represented, as lately erected in Westminster Abbey". ${ }^{31}$

But, by 1769 , Garrick had allowed the sacred spot to shift again, this time to Stratfordupon-Avon in the event that would be explicitly established as a religious one in its very title, the Jubilee. Garrick set out to privilege the birthplace over the rival attractions in Stratford:

The Gothic glories of the ancient Church, the modern elegance of the Civic Hall, cease to be regarded, when it is remembered that the humble shed, in which the immortal bard first drew that breath which gladdened all the isle, is still existing; and all who have a heart to feel, and a mind to admire the truth of nature and splendour of genius, will rush thither to behold it, as a pilgrim would to the shrine of some loved saint; will deem it holy ground. ${ }^{32}$

Not quite a manger but the next best thing, this shed was to be more even than the shrine of a saint. Think back to William Cowper (quoted above) on Garrick "fram[ing] the rites". James West noted on a letter from Garrick about the Jubilee on 19 May 1769, "In Stratford, Garrick bows to Shakespeares Shrine". ${ }^{33}$ Long after the Jubilee, as Garrick wrote to Stratford's Mayor to outline future annual events which "should be on his Birth-day", he encouraged the Mayor to ensure the cleanliness of the town to "allure Every body to Visit $\mathrm{y}^{\mathrm{e}}$ holy Land", as if Stratford and Bethlehem were indeed indistinguishable. ${ }^{34}$ And the very notion of a jubilee, as Garrick hatched the plan with the burgesses of Stratford-upon-Avon, was designed to evoke pilgrimage and religion from its origins in Leviticus through Pope Boniface VIII's institution in 1300 of a period of remission from punishment for sin consequent on pilgrimage to Rome. Whatever else it was, the Stratford Jubilee was to be the creation of a national religious cult of Shakespeare worship.

I do not of course want or need to go over the events in Stratford, well described by Deelman and England, ${ }^{35}$ beyond pointing out Garrick's commissioning Gainsborough to rework the portrait of Garrick with the bust of Shakespeare that had been exhibited in 1766, with Garrick in a cross-legged stance that deliberately echoes both the Westminster Abbey statue and the Roubiliac in Garrick's temple. The function of the 
event as ritual, its liturgical patterning, has been beautifully explored by Péter Dávidházi, ${ }^{36}$ from the lunch for 700 people with its toasting Shakespeare in wine (shades of the Last Supper here) to Garrick's song in praise of the mulberry tree cup with its clear signs? of Eucharistic adoration of this version of the Holy Grail:

Behold this fair goblet, 'twas carv'd from the tree,

Which, O my sweet Shakespeare, was planted by thee;

As a relick I kiss it, and bow at the shrine,

What comes from thy hand must be ever divine!

All shall yield to the mulberry-tree,

Bend to thee,

Blest Mulberry,

Matchless was he

Who planted thee,

And thou like him immortal shall be! $!^{37}$

What most intrigues me is not the events in Stratford but the repossession of the event by the theatres in London and the pamphleteering and other publications that also, at times, recreated the Jubilee as drama. And, within that process, there is a continual anxiety over the term "Jubilee" itself, with its Catholic origins. Punningly, the Jubilee also linked to the controversy over the Jewish Naturalization Act of 1753, often referred to as the "Jew-bill", an Act, promoted by the Whigs and fiercely opposed by the Tories, that, in gratitude for Jewish support during the Jacobite rising of 1745, allowed Jews to be naturalized as British citizens but which was inevitably attacked as an abandonment of the Christian basis of the country. ${ }^{38}$ If Garrick's own version of the Shakespeare religion is something I have been defining as unconcernedly incoherent, then the consequence of the remediation of its most public manifestation at the Jubilee was only a magnification of that incoherence and conflictedness, itself a source of cultural anxiety rather than reassurance, now by contemporary playwrights and critics, literati and literary hacks, playgoers and readers.

To document something of the scale of the response to the events in Stratford I need first to offer a short table of the Jubilee plays and prologues for London and a few of the associated pamphlets published in the capital:

1. Barely a week after the Jubilee had begun, on $13^{\text {th }}$ September, Samuel Foote added a speech for the Devil in his play The Devil upon Two Sticks that offered a definition of a Jubilee as "a public invitation...to celebrate a great poet whose works have made him immortal by an ode without poetry, music without melody, dinners without victuals and lodgings without beds". 39

2. George Colman's prologue, "Scrub's Trip to the Jubilee", was performed by Weston at Covent Garden on September $19^{\text {th }}$.

3. Francis Gentleman's play, The Stratford Jubilee, was intended for Samuel Foote's company at the Haymarket but never performed. It was published, with Colman's prologue, on the same day.

4. Garrick's Vagary, an anonymous satire in dialogue-form, was advertised on $22^{\text {nd }}$ September.

5. Garrick performed the Ode on stage at the Theatre Royal, Drury Lane on $30^{\text {th }}$ September and repeated it on a few days thereafter.

6. Foote announced that his theatre would perform a Burlesque Jubilee Ode with a parody of the Drury Lane procession of characters, dressed in rags, but was eventually dissuaded from doing so. Drugger's Jubilee, a reference to Garrick's role in Jonson's The Alchemist, was still being anticipated in May 1770.

Actes des congrès de la Société française Shakespeare, 33 | 2015 
7. George Colman's play Man and Wife, hastily rewritten to include satire on the Jubilee and including a pageant of Shakespeare's characters, was first performed at Covent Garden on $7^{\text {th }}$ October 1769.

8. Garrick's The Jubilee followed at Drury Lane on $14^{\text {th }}$ October.

9. Anti-Midas, a pamphlet defence of Garrick's Ode, was probably published in November.

10. Edward Thompson's poem, Trinculo's Trip to the Jubilee, also appeared in November.

11. Henry Woodward's pantomime, Harlequin's Jubilee, opened at Covent Garden in January 1770.

12. And Peter Barnes' play Jubilee was first performed by the Royal Shakespeare Company in the Swan Theatre, Stratford-upon-Avon, in July 2001.

Put simply, I can think of no comparable case of such repeated remediation of an event into theatre, poem, pamphlet and parody. And in spite of the sustained mockery for the Ode, the rapacious inhabitants of Stratford, the weather and other such failures, there is really no mockery of the idea of celebrating Shakespeare in some such extravagant fashion. Only in the last two items on my list is there a thought of an alternative. Barnes' play includes the appearance in Garrick's dream of Peter Hall, Trevor Nunn and Terry Hands who encourage Garrick in the project: as Hall says, "If you don't say 'yes', there'll be no Shakespeare Jubilee, no memorial Theatre, no plays, no money and no prestige", while Hands adds "Without him...[w]e might even have to get different jobs. But we've no training, no experience, no aptitude." ${ }^{40}$ This scene imagines the consequence of there being no Jubilee but Barnes also envisages a different celebration. As Hermione, the maidservant in Mrs Ross's brothel puts it,

why celebrate Shakespeare?...While you celebrate him, the real world is being forgotten for a verb or a noun...What does Shakespeare know of the terror of my life...? Don't cry over his verse, cry over my life. ...Celebrate me! Celebrate me! (op. cit., p. 43).

Woodward's play was not published but its songs were and Woodward's parody of Garrick's song "The lad of all lads was a Warwickshire lad" as the competition between two pubs, both called The Magpie, that traded on the London Road, ends with a recognition of where power really lies: "Pro Publico bono will shew his best skill, / For the will of all wills is the Public's good will; / Public's good will! / Matchless still!" ${ }^{41}$ The farce ended with a hymn of praise to Lun: "Songs grotesque, and jocund raise, / To LUN, who merited our praise!" As a reviewer described, the play closed "with the descent of the statue of the late Mr Rich, under the name of Lun, which he always adopted when he performed the character of Harlequin", especially appropriate as, when Woodward played Harlequin, he used the name Lun, Jr. ${ }^{42}$ The celebration of Lun's triumph is an ironic reversal of James Miller's Harlequin-Horace (1735), an attack on Rich exactly for his o'ertopping Shakespeare. And it is also a reflection of the theatrical squabble in 1750 between Rich and Garrick when several of Garrick's actors left Drury Lane for Rich's company. Garrick won the battle when he put on Queen Mab, starring as Harlequin Henry Woodward. A contemporary print, "The Theatrical Steel-yards", shows Garrick outweighing Rich's stars, with Woodward hanging up Queen Mab to tip the balance. ${ }^{43}$

Of course there is repetition among all these representations. Samuel Foote's mockery was taken over by many, most effectively by Garrick himself who turned it into a song: "Odes, Sir, without poetry / Music without melody / Singing without harmony." ${ }^{44}$ The clash between London's fashionable elite, out for a good time, and provincial cunning, 
out for a profit, is an inevitable meme in most of these. But so is the repeated concern to define the Jubilee as nothing whatsoever to do with the decrees of the Pope and the remissions of sins sought by Roman Catholics. The word Garrick chose seems in this context to be recurrently troubling, even though there had been no shortage of uses earlier as part of national celebrations, such as the actor Richard Estcourt's ballad "Britain's Jubilee" on Marlborough's victories over the French, published in $1708{ }^{45}$ or Rev Joseph Acres' sermon preached on the accession of George I, Great Britain's Jubilee or the Joyful Day (1715). And Farquhar's play, The Constant Couple, subtitled A Trip to the Jubilee, a staple of the repertory throughout this period, made the actor Henry Norris famous as "Jubilee Dicky" and mocked the foolish character Clincher senior for wanting to go to the Jubilee when all he can say about it is "why the Jubilee is - faith I don't know what it is". ${ }^{46}$

In 1769 the separation of the Stratford celebrations from the events in Rome, where, every fifty years, the Jubilee was marked by pilgrimages and the remission of sins (most recently in 1750), seemed crucial. Otherwise the country would have been left with the assumption that, as a character in Francis Gentleman's The Stratford Jubilee put it, "the Jubilee...is a rank piece of popery." ${ }^{47}$ Here, for instance, is a character in Colman's Man and Wife: "If it is a Jubilee, it must be nonsensical. - I was at the Jubilee at Rome some years ago." ${ }^{48}$ Or, again, from the same play, "you care no more for Shakespeare, than I for the Pope of Rome". ${ }^{49}$ (Colman, incidentally, offers what is my favourite label for Shakespeare: "Shakespeare, Mr. Marcourt - Shakespeare is the Turtle of Literature. The lean of him may perhaps be worse than the lean of any other meat; - but there is a deal of green fat, which is the most delicious stuff in the world." ${ }^{50}$ The phrase is probably an echo of the fact that an enormous turtle, $327 \mathrm{lbs}$ in weight, had been served at one of the Jubilee banquets. ${ }^{51}$ )

Garrick's play has Nancy announce to Sukey "I swear I know no more about the Jubillo and Shakespur, as you call him, tha[n] I do about the Pope of Rome". Sukey, who "cried for a whole night together after hearing his Romy and July at Birmingham", tells Nancy off: "Had you lived at Birmingham or Coventry, or any other polite cities, as I have done, you would have known better than to talk so of Shakespur and the Jewbill". ${ }^{52}$ Garrick was, indeed, concerned before the event at rumours of the locals' suspicions, writing to William Hunt, Stratford's Town Clerk, on 16 August 1769,

I heard Yesterday to my Surprize, that the Country People did not seem to relish our Jubilee, that they look'd upon it to be popish \& that we $\mathrm{sh}^{\mathrm{d}}$ raise $\mathrm{y}^{\mathrm{e}}$ Devil, \& $\mathrm{w}^{\mathrm{t}}$ not - I suppose this may be a joke, - but after all my trouble, pains labor \& Expence for their Service \& $\mathrm{y}^{\mathrm{e}}$ honor of $\mathrm{y}^{\mathrm{e}}$ County, I shall think it very hard, if I am not receiv'd kindly by them - how ever I shall not be the first Martyr for my Zeal.

In a postscript he asked Hunt to "pray tell me Sincerely what the Common People think \& Say. ${ }^{53}$ He turned the joke to his own use in his play but the anxiety here sounds real enough.

At its most extreme, the comparison between a celebration of the national poet and the threat of a foreign and subversive religion was carefully and anxiously pursued in the pamphlet-dialogue Garrick's Vagary. The author spends page after page charting the similarities between the events of the Stratford jubilee and the precise rituals of the jubilee at Rome, so that, for instance, 
holding a golden Hammer in his Hand, that is, the Ticket, which cost him a Guinea, he knocks at the Gate three Times, from a natural Impatience to get in, and have a good Seat, repeating these Words, Aperite mihi Portas justitiae, \&c. Open the Door, for I have a just Right to in and hear the Praise of Shakespeare.

Or for the moment when the Pope takes up the cross and enters St Peter's,

Here we are to substitute our Roscius, entering the Booth at Stratford, followed by all his theatrical Tribe, of various Denominations; and then, taking up not the Cross, but the Ode, he begins to read... ${ }^{54}$

The sign of Christianity becomes the poem in praise of Shakespeare, creating a remarkable analogy. It is Garrick who pinpoints the convergence of papacy and the jubilee in the transformation of the Shakespeare monument in Holy Trinity Church, when Ralph, a Stratford local, says, with provincial wisdom, "I knew something was abrewing when they would not let his image alone in the church, but had the show people paint it in such fine colors to look like a Popish saint." ${ }^{55}$ Shakespeare painted is Shakespeare the Catholic saint. The writer who in national pride signifies the triumph of Protestantism is painted into the Catholic tradition.

Garrick's Vagary opens with an attack on everyone in London,

running out of Town, pell-mell, after a Brat of Judaism, a since foster-Child of Popery, now, forsooth, revived by an Actor, to the very imminent and most alarming Danger both of Church and State - As a good Englishman, and a true Protestant, I feel much Concern, am patriotically hurt,...at so papistical a Manœuvre,...I wonder how our Bishops can remain quiet on so critical an Innovation... ${ }^{56}$

The new Shakespeare religion, the cult of Shakespeare, is a threat to the coherence of the country's view of state and church and a sign of the invasive otherness of foreign religions like Judaism and Roman Catholicism. The interweaving of patriotism and antipopery would reach a new stage a few years later when the Papists Act of 1778 led to the Gordon Riots in 1780. The rise of the Shakespeare religion comes to pinpoint cultural anxiety, social vulnerability and national insecurities in the very Englishness it was aimed to celebrate. ${ }^{57}$

It is no surprise, then, that the Stratford Jubilee would lead to a proposal of yet another quasi-religious structure, another Shakespeare temple, not this time in the gardens of an actor who wished to appear a gentleman but as a public structure to celebrate the glory of the nation. Paul Hiffernan, like Francis Gentleman a Dubliner, was another playwright, poet, critic, hack, eking out a living in London. Helped by Garrick's drumming up subscriptions, Hiffernan published in 1770 his study of Dramatic Genius, the first book of which sets out his "Plan of a permanent Temple, to be erected to the memory of Shakespeare, in a Classical Taste; with Inscriptions and Decorations, suitable to the Objects chosen" (p. v). The inscriptions were to be in Latin and English, "the one for the sake of learned Foreigners unacquainted with our Language, and by whom we are now visited in greater numbers than usual heretofore" (p. 3-4), a sign of Shakespeare's potential interest for the developing tourist trade. Whatever the Jubilee might have done for Stratford and whatever Garrick may have done at his villa in Hampton, Hiffernan wanted to see extended to the proper kind of shrine to the poet and his actor, with scenes from tragedies and comedies but, intriguingly, without 
Othello because "the blacking screens, and renders incommunicable to spectators, all impassioned working of the countenance" (p. 6).

The exterior inscription, in Hiffernan's own awkward translation of his awkward Latin, was to read:

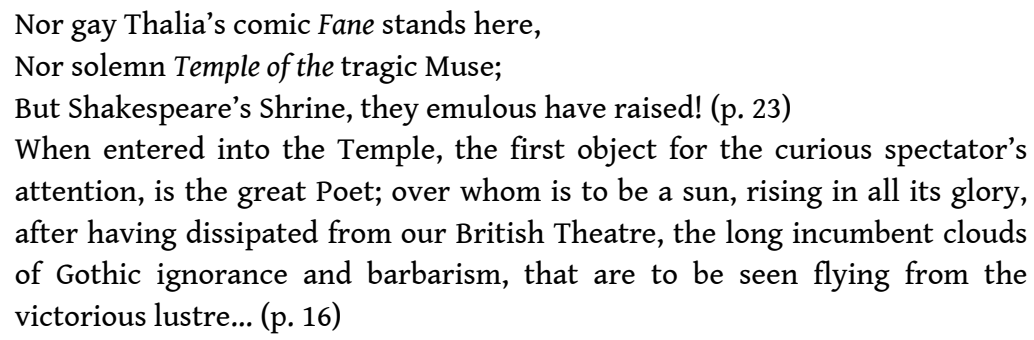

But, if that suggests the sun behind shakespeare, the inscription shows that Shakespeare himself is the source of the light and power: "Darkness' dark shades fly Shakespeare's solar Beams" (p. 16).

Shakespeare is the blessed sun, an Apollonian transfiguration; the saint in whose honour the temple is created as a "shrine", Hiffernan's word, has become fully divine, the energy for the world or more especially nation. Not a place for Shakespeare's relics like Garrick's collection in his temple, mulberry chair and all, but a place of pilgrimage to see the classical divine and the beatified Christian united against foreign darkness. No wonder Hiffernan wanted the foreign tourists to understand the message. No wonder this supremely hyperbolic architectural vision was never built. Shakespeare commemoration may often be grand or even grandiose but nothing out-tops Hiffernan's fantasy.

In Desert Island Discs, the world's longest-running radio programme, a celebrity "castaway" is asked to choose, as well as eight records, a book other than The Bible and the works of Shakespeare, which somehow have reached the desert island already. In the same way, the progress from Basse's poem, through the parodic naming of Shakespeare as a saint, through the temples and statues, idolatry and popish celebrations that I have charted, ends in an equivalence: the works of Shakespeare and the Bible are really the same thing, both the Word of God. As Lichtenberg noted in 1775, the audience at Hamlet's "To be or not to be" "not only knows it by heart as well as they do the Lord's Prayer, but listens to it, so to speak, as if it were a Lord's Prayer... In this island Shakespeare is not only famous, but holy." 58

Lichtenberg was no more likely than Garrick to unpack the complex and conflicting notions of faith and adoration sitting within that short word "holy". As usual, the imprecision is central to the possibility of turning fame into sainthood. 


\section{NOTES}

1. An earlier version of this article was given at the Shakespeare 450 Conference in Paris in April 2014. My thanks to Dominique Goy-Blanquet for the invitation to lecture on Shakespeare's "birthday".

2. All quotations from Shakespeare are from The Complete Works, ed. Stanley Wells, Gary Taylor et al., Oxford: Clarendon Press, 1986. The passage from The Two Noble Kinsmen is from a scene usually attributed to Fletcher.

3. Johann Wolfgang von Goethe, "Speech on the Shakespeare Day", Comparative Criticism 7 (1985), 177-181, p. 180.

4. Ian McIntyre, Garrick, London, Allen Lane, The Penguin Press, 1999, p. 233.

5. For the best study of these paintings and of Garrick's long and complex relationship with Zoffany, see Mary Webster, Johann Zoffany 1733-1810, New Haven, Yale University Press, 2011, esp. ch. 4 "The Patronage of David Garrick", p. 75-91.

6. George Winchester Stone, Jr., and George M. Kahrl, David Garrick: A Critical Biography, Carbondale, Ill., Southern Illinois University Press, 1979, p. 429.

7. David Garrick, Plays, ed. Harry W. Pedicord and Frederick L. Bergmann, 7 vols., Carbondale, Ill., Southern Illinois University Press, 1980-2, 2:112.

8. Stone and Kahrl, op. cit., p. 429.

9. Henry Walpole, Private Correspondence, 3 vols., London, Henry Colbourn, 1837, 1:349.

10. David Garrick, The Letters of David Garrick, ed. David M.Little and George M.Kahrl, 3 vols., London, OUP, 1963, Letter 362, 2:463.

11. Quoted by Michael Dobson, The Making of the National Poet, Oxford, The Clarendon Press, 1992, p. 182. Little of this article would have been possible without Dobson's brilliant and pioneering work in this field.

12. David Garrick, The Poetical Works, 2 vols., London, George Kearsley, 1785, 1:57.

13. Stone and Kahrl, op. cit., p. 408.

14. Reprinted in Anti-Midas (1769), p. 23.

15. Ibid., p. 23-4.

16. Cowper, The Task, Bk 6, in William Cowper, The Poetical Works, ed. H.S. Milford, $4^{\text {th }}$ ed., London, OUP, 1934, p. 234.

17. William Roberts, Memoirs of the Life and Correspondence of Mrs Hannah More 2 vols., New York, Harper Brothers, 1834, 1:34.

18. "Shakespeare and Celebrity Culture", paper at the Shakespeare and the Problem of Biography conference, Folger Shakespeare Library, 4 April 2014.

19. Quoted by Peter Holland, "Shakespeare and the DNB" in J.R. Mulryne and T. Kozuka, eds., Shakespeare, Marlowe, Jonson: New Directions in Biography, Aldershot, Ashgate, 2006, 139-49, p. 140.

20. George Thorn-Drury, More Seventeenth Century Allusions to Shakespeare and his Works, London, P.J. and A.E. Dobell, 1924, p. 4.

21. Though the date looks like a Julian/Gregorian calendar discrepancy, England used the Julian calendar until 1752 and hence 4 May 1660 was the same as 4 May 1564. In addition, the baptismal register entry for Shakespeare had not yet been identified and therefore the extrapolation to the supposed birthday had not been made.

22. Frank Palmeri, "History, Nation, and the Satiric Almanac, 1660-1760", Criticism 40 (1998),

$377-408$, p. 384.

23. Thorn-Drury, op. cit., p. 15.

24. William Winstanley, Lives of the Most Famous English Poets (1687), p. 130.

25. Jackson C. Boswell, 'Yet Another "New" Shakespeare Image', SQ 60 (2009), p. 341-347. 
26. Winstanley, op. cit., p. 31, 182.

27. See the print, e.g. at the National Portrait Gallery, NPG D7658, http://www.npg.org.uk/ collections/search/portrait.php?search=ap\&npgno=D7658\&eDate=\&lDate=, accessed 3 June 2014.

28. See, among much other work, Don-John Dugas, Marketing the Bard: Shakespeare in Performance and Print, Columbia and London, University of Missouri Press, 2006.

29. Quoted by Vanessa Cunningham, Shakespeare and Garrick, Cambridge, CUP, 2008, p. 8.

30. Vickers, op. cit., 3:365-6.

31. Quoted Dobson, op. cit., p. 163.

32. Quoted in Jonathan Bate, Shakespearean Constitutions: Politics, Theatre, Criticism, 1730-1830, Oxford, OUP, 1989, p.31.

33. Garrick Letters, Letter 538, 2:644.

34. Garrick, Letters, Letter 625, 2:728, dated 8 March 1771.

35. Christian Deelman, The Great Shakespeare Jubilee, London, Michael Joseph, 1964; Matha W. England, Garrick's Jubilee, Columbus, Ohio, Ohio State University Press, 1964.

36. See Péter Dávidházi, The Romantic Cult of Shakespeare, Houndmills, Basingstoke, Macmillan, 1998, passim; and his “'He drew the Liturgy, and framed the rites': The Changing Role of Religious Disposition in Shakespeare's Reception", Shakespeare Survey 54 (2001), 46-56.

37. David Garrick, The Poetical Works, 2:431.

38. On this see James Shapiro, "Shakespur and the Jewbill", Shakespeare Survey 48 (1996), 51-60.

39. Deelman, op. cit., p. 272.

40. Peter Barnes, Jubilee, London, Methuen, 2001, p. 30-1.

41. Henry Woodward, Songs, Choruses, \&c., As they are performed in the new Entertainment of Harlequin's Jubilee, London, 1770, p. 7.

42. Quoted Dobson, op. cit., p. 216n.

43. See Marcus Risdell, "Picturing Rich" in "The stage's glory”: John Rich, 1692-1761, ed. Berta Joncus and Jeremy Barlow, Newark, University of Delaware Press, 2011, p. 266-72.

44. Garrick, Plays, 2:107.

45. In Windsor Castle: A Poem, London, 1708, p. 15-16.

46. George Farquhar, Works, ed. Shirley Strum Kenny, 2 vols., Oxford, Clarendon Press, 1988, 1:168.

47. Francis Gentleman, The Stratford Jubilee (1769), p. 4.

48. Colman, Man and Wife (1770), p.17.

49. Ibid., p. 22.

50. Ibid., p. 19.

51. Deelman, op. cit., p. 234.

52. Garrick, Plays, 2:122.

53. Garrick, Letters, Letter 553, 2:660. My thanks to Michael Dobson for drawing this letter to my attention.

54. Garrick's Vagary (1769), p. 16, 19.

55. Garrick, Plays, 2:105.

56. Garrick's Vagary, p. 3-4.

57. Michael Dobson suggests that Garrick's Jubilee was, in part, a tribute to the Wilkes Jubilees (Making of the National Poet, p. 218-19, n.48) but I can trace no reference to the Wilkes celebrations as "jubilees" prior to the Stratford events.

58. Margaret L. Mare and W.H. Quarrell, Lichtenberg's Visit to England, Oxford, Clarendon Press, 1938 , p. 16. 


\section{ABSTRACTS}

Temples built and imagined, statues sculpted and copied, proposals made and ignored, events celebrated and mocked, pamphlets published, shakespeare canonized, high priests selfappointed and so on. My paper will consider some of the processes of celebration and commemoration from Shakespeare's death until the Jubilee.

Des temples érigés et rêvés, des statues sculptées et copiées, des propositions faites et abandonnées, des événements organisés et décriés, des ouvrages publiés, Shakespeare canonisé par des célébrants auto-proclamés, et ainsi de suite. Cet article étudie les procédés de célébration et de commémoration de Shakespeare de sa mort au « Jubilée » de 1769.

\section{INDEX}

Keywords: 1769 Jubilee, Garrick David, Hiffernan Paul, Winstanley William, bardolatry, celebration, commemoration

Mots-clés: Garrick David, Hiffernan Paul, Jubilée de 1769, Winstanley William, bardolâtrie, célébration, commémoration

\section{AUTHOR}

\section{PETER HOLLAND}

University of Notre Dame 